\title{
RAMS ANALYSIS OF RAILWAY VEHICLES' LIFECYCLE
}

\author{
ANALIZA RAMS W CYKLU ISTNIENIA \\ KOLEJOWYCH ŚRODKÓW TRANSPORTU
}

\author{
Maciej Szkoda, Grzegorz Kaczor \\ Cracow University of Technology \\ Politechnika Krakowska
}

\begin{abstract}
The presented paper investigates the issues concerned with the RAMS analysis with the reference to the railway means of transport. The RAMS analysis includes the quantitative and qualitative indicators of degree, that the system and its components will meet all the assumed functions preserving the requirements of the availability and safety. RAMS is a long-term process, resulted from the applied tools and techniques throughout the life cycle of railway means of transport. The overall guidelines related to the development of RAMS features are included in $P N-E N 50126$ Railway Applications - The Specification and Demonstration of Reliability, Availability, Maintainability and Safety (RAMS).
\end{abstract}

Keywords: life cycle, RAMS analysis, railway means of transport

Streszczenie: $W$ pracy na podstawie wytycznych zawartych $w$ normie PN-EN 50126 Zastosowania kolejowe - Specyfikacja niezawodności, dostępności, podatności utrzymaniowej i bezpieczeństwa, przedstawiono wybrane zagadnienia dotyczace ksztaltowania charakterystyk RAMS kolejowych środków transportu. Analiza RAMS odnosi się do ilościowych $i$ jakościowych wskaźników niezawodnościowych, charakteryzujących $w$ jakim stopniu system, podsystem i jego elementy, będa spetniać wszystkie założone funkcje, zachowując przy tym wymagania gotowości $i$ bezpieczeństwa. Jest to proces dtugoterminowy, wynikajacy $z$ zastosowanych narzędzi oraz technik $w$ cyklu istnienia kolejowych środków transportu.

Slowa kluczowe: cykl istnienia, analiza RAMS, kolejowe środki transportu 
RAMS analysis of railway vehicles' lifecycle

Analiza RAMS w cyklu istnienia kolejowych środków transportu

\section{Introduction}

Railway vehicles are complex technical objects characterised by high costs of purchase and operation and a long period of use for which the set of parameters describing the stages of their definition, design, manufacture and operation is very extensive and varied. These objects are designed to meet demanding regulations on the safety of use and must be characterised by the lowest possible intensity of occurrence of hazardous events that may disturb their correct functioning. The safety of railway means of transport relates strictly to their reliability which may be determined at the stage of their design, manufacture and operation. The condition for ensuring the required reliability level is, in turn, inter alia, an appropriately designed maintenance system taking into account the optimum frequency and scope of maintenance. A plan for the system of maintenance of railway means of transport must be devised so as to enable early detection of at least critical failures in order to keep the required safety level. Maintenance activities (corrective ones in particular) on railway means of transport involve costs and hence the development of mathematical models for the purposes of forecasting the maintenance frequency seems to be fully justifiable.

The RAMS (Reliability, Availability, Maintainability and Safety) analysis is a tool commonly applied for the needs of various industries, railway transport in particular. Despite a considerable potential of the aforementioned method, certain gaps can be noted in the standardisation of the calculation procedures especially as regards the determination of measures (indicators) relating to the reliability of railway means of transport. The standard PN-EN 50126 Railway Applications The Specification and Demonstration of Reliability, Availability, Maintainability and Safety [10] provides guidelines on the application potential of the RAMS analysis in the railway sector which, however, do not cover certain practical aspects in their entirety.

The aim of the RAMS analysis is to use operational information to perform an assessment of compliance with the requirements set out in the standard PN-EN 50126. These requirements concern specific indicators of reliability, availability, maintainability and safety. A major role in the RAMS analysis is played by the accuracy of operational information. Thus, such data should be collected by railway carriers with particular diligence and captured in special database sheets. The data structure should provide for a description, as detailed as possible, of the cause of failures, the time of their occurrence and the scope of maintenance activities which have been undertaken. Also, quick access to the contents of the sheets is important [6].

The present paper discusses the application of the RAMS analysis in the lifecycle of railway means of transport. The key notions and indicators are cited which serve the purpose of assessing the reliability, widely understood, of railway means of transport, in accordance with the standard PN-EN 50126. 


\section{Basic notions relating to the RAMS analysis of railway means of transport}

Reliability of railway means of transport is a collective property comprising such characteristics of a vehicle as: reliability, availability, maintainability and safety (Fig. 1).

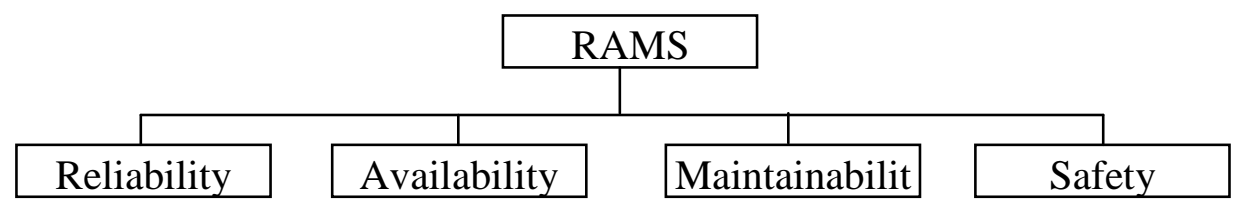

Fig. 1. RAMS components for railway means of transport

The RAMS analysis guidelines for railway means of transport are covered by the standard PN-EN 50126 Railway Applications - The Specification and Demonstration of Reliability, Availability, Maintainability and Safety. These features can be defined as follows [10,12, 13]:

Reliability is understood as the vehicle's ability to perform the required functions in particular operational conditions and within a particular time range.

Availability is the vehicle's ability to remain in a condition enabling it to perform the required functions in particular conditions, at a particular moment or within a particular time range assuming that the required external means are provided.

Maintainability is defined as a property characterising adaptability to the provision of services in order to restore the condition of availability in particular conditions of operation with the use of pre-determined methods and means.

Safety means the absence of an unpermitted risk which describes the frequency of accidents and incidents leading to a failure (caused by a hazard) and the gravity of such failure [11]. According to the definition in the standard PN-EN 50126, safety means the absence of catastrophic consequences for the user and the environment.

\section{Shaping RAMS properties in the lifecycle of railway means of transport}

According to PN-EN 50126, the RAMS analysis is a process of designing, monitoring and improving indicators of reliability, availability, maintainability and safety in the lifecycle of a railway vehicle. The process of determining the RAMS properties which is outlined in Fig. 2, is a multi-stage one. It goes through all stages of the vehicle's lifecycle: from the creation of its concept and design through manufacturing to operation.

During stage one of the process of determining RAMS properties, the target RAMS parameters are set. To this end, it is important to take account of the client's requirements and needs. The client can be a railway transport company which operates the vehicle. 
RAMS analysis of railway vehicles' lifecycle

Analiza RAMS w cyklu istnienia kolejowych środków transportu

In the US market, standardised forms the template of which is provided in the $D o D$ Guide for Achieving Reliability, Availability and Maintainability [4]. Identification of parameters of vehicles of similar types offered in the market by competitors is also valuable.

Following the stage of definition and concept, the process of determining the RAMS properties goes through the stage of designing the vehicle. The determination of the level of reliability is most effective in economic terms at the design stage. It means that the intended reliability level requires at this stage considerably lower outlays compared to where this level is reached at the other stages as a result of additional measures not envisaged at the design stage. It can therefore be concluded that measures to achieve reliability at the design stage are particularly justified. Some of them have been known and applied for a long time now. They are usually qualitative in their nature and do not require the designing engineer to know reliability theories. Measures of this type include [15]:

- designing objects of little complexity,

- reasonable application of safeguards, stops and indicators,

- ensuring easy replacement of elements (through, inter alia, the application of modular structures of certain fragments of the object),

- providing the designed object with low sensitivity to workmanship and operation errors,

- designing ways of reducing the intensity of physical phenomena aggravating the technical condition of the object during its operation (e.g. reducing the strain levels, choice of appropriate materials, eliminating hazardous vibrations),

- choice of appropriate manufacturing methods (inter alia, thermal and chemical treatment),

- formulating appropriate requirements in assembly, operations and maintenance manuals (concerning, inter alia, preventive maintenance and diagnosis of the technical condition),

- proper mapping of the operation process at the stage of experimental tests of the prototype,

- organising a system to collect and transfer information about the object from the stages of manufacture and operation to the stage of design.

Other measures - quantitative ones - intended to attain the reliability of the designed object are also possible. Their application requires the knowledge of the foundations of reliability analysis that is, in the first place, the ability of probabilistic modelling of the object's properties and of the phenomena in and around the object during its operation that lead to its unavailability. The principal aim of the reliability analysis, especially at the vehicle design stage, should be to indicate the factors which have the greatest effect on its reliability level. Such a result of the reliability analysis makes it possible to choose the most effective methods for improving reliability. Reliability analyses for objects are usually performed on their models. 
In a general case, a reliability-based model of an object is a system which, in terms of reliability, maps the actual object and replaces it in the planned reliability analyses. The form of the model depends on a number of factors such as: object type, aim of the study, scope of information about the object and its surroundings, etc.

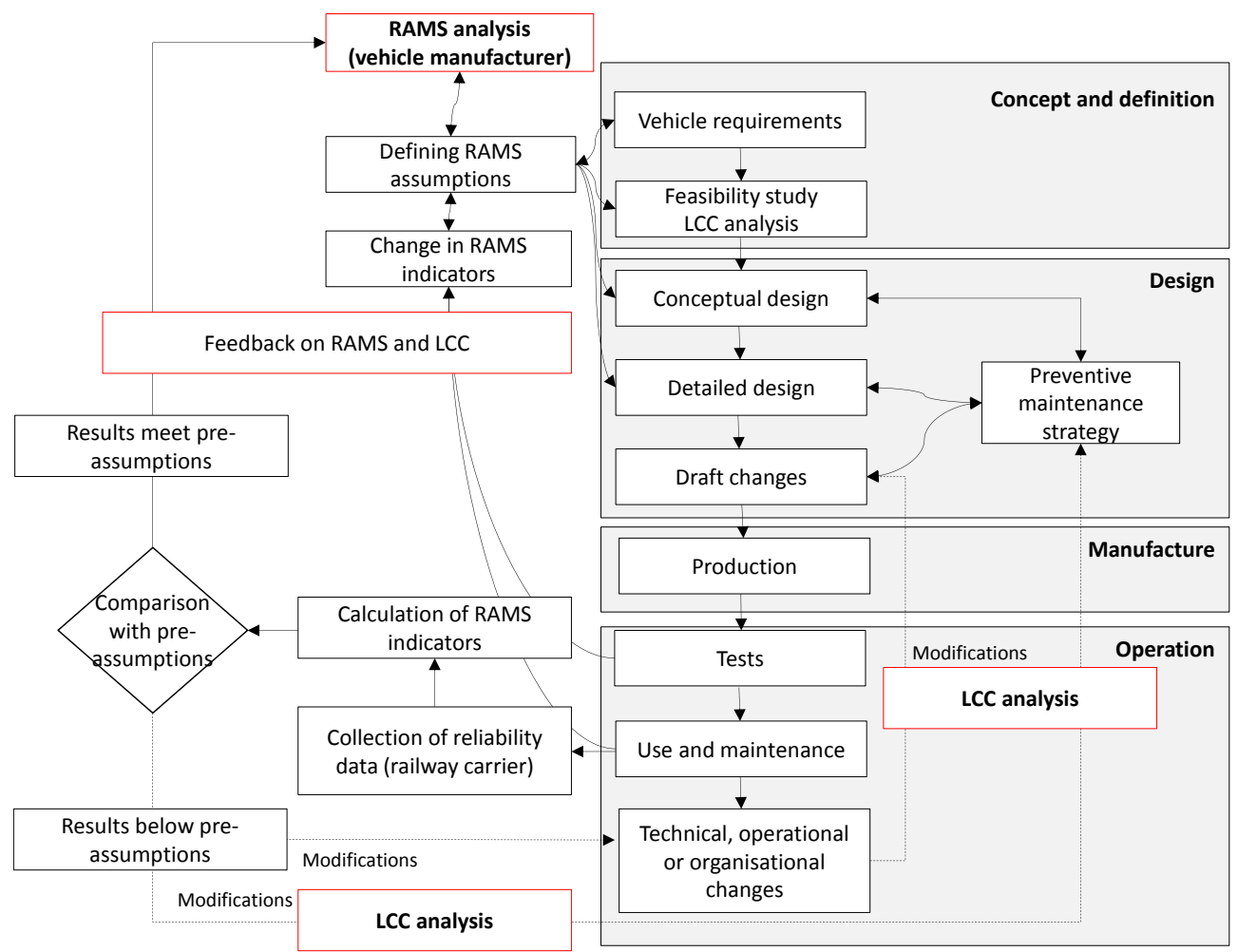

Fig. 2. Process of determining the RAMS properties of railway means of transport

In the case of an object treated as an object composed of elements of known reliability, its reliability model is in principle reduced to a model of its reliability structure. Serial structures with a reserve or threshold ones of the type $k z n$ apply to railway means of transport $[5,9,15]$. Examples of modelling reliability structures for railway gauge changing systems are presented in [14].

The vehicle's design should be done in parallel with an assessment of the maintainability of assemblies and subassemblies and the development of a maintenance strategy. The manner of conducting maintenance processes can be influenced through various structural solutions, the modular structure and the provision of easy access to sub-assemblies. As the vehicle's structure emerges, its RAMS properties become increasingly difficult to change. The provision of correct RAMS parameters at the manufacturing stage concerns, inter alia, the application of proper quality assurance methods. 
RAMS analysis of railway vehicles' lifecycle

Analiza RAMS w cyklu istnienia kolejowych środków transportu

After manufacture, the vehicle goes into operation, initially so-called supervised operation intended to perform the required tests to allow its operation which is then followed by commercial operation proper.

The stage of operation is a major source of information in the determination of the RAMS properties of railway means of transport. The notion of operational information should be understood to mean any data on the phenomena occurring in the sphere of vehicles' operation, that is their use and maintenance. Such data can be used for the purposes of planning and managing operation, improving the technology and structure of the operated vehicles as well as controlling the RAMS indicators. Such a definition of operational information enables its identification with economic information on the conduct of operational processes and technical information which characterizes vehicles in the conditions of their operation.

Operational information plays a major role for carriers who use the vehicles because they enable proper planning of their operation, planning of downtimes and maintenance and the assessment of utilization of the means of transport [10]. From the viewpoint of the manufacturer of a vehicle (or its components), operational information constitutes a control element and a source of comparative data to assess the attainment of the target technical level, enable data to be collected on the required number of spare parts and the operational cost, and constitute a form of exchange of information with the user to identify its needs, wishes and remarks. Information on RAMS indicators and the costs which are generated can be divided into:

- operational information which forms the basis for controlling the processes on an ongoing basis,

- emergency information communicating incorrect operation of a vehicle.

Emergency information forms the basis for developing a statistical assessment of hazardous events. Over a longer term, the archived data may create a database of different variables describing the process of operation. Such variables have the form of discrete variables (number of events) or continued variables (variables describing the time, efficiency, distance, etc.). The writings on the subject include papers on the development of professional information systems applied in the operation of technical objects.

As presented in Fig. 2, actual data gathered by a carrier and relating to the statistics of failures and repairs provide feedback for the design stage. If the vehicle's reliability level is unsatisfactory, it is possible to introduce structural, operational or organisational changes to attain the required level of reliability and safety. This requires cooperation and exchange of data between the carrier operating the vehicle, the party that maintains it and the vehicle's manufacturer. 


\section{Sources of data for RAMS analysis}

An assessment of reliability of railway means of transport requires the collection and processing of reliable operational data. Such data are gathered as a result of observation of operations done passively or actively.

In an active observation experiment specific data selected to meet the aim of the study are gathered which requires the application of special data collection procedures and forms $[1,8]$. Passive observation of operation consists in the processing of existing data recorded in the carrier's routine files. In the case of traction vehicles, these will include:

- corrective maintenance logbook,

- preventive downtime and maintenance logbook,

- traction vehicle logbook and other.

Polish railway carriers are noted to be applying, increasingly frequently, advanced IT systems to support the management of their transport capacity (such as the Electronic Logistics Book at PKP Cargo S.A.). Simple applications are also in place and these use the Microsoft Excel package which facilitates considerably the collection and analysis of operational data forming the basis for reliability assessment. An example of a MS Excel spreadsheet structure used to gather operational data concerning corrective maintenance of traction vehicles is presented in Table 1. A key problem in tools of this type is the development of a universal catalogue of failures broken down by vehicle assembly and subassembly (so-called failure code). Table 1 gives an example of such registers applied to diesel locomotives at PKP Cargo S.A. which can be a model to follow for other Polish railway carriers.

During the collection of operational data and their subsequent analysis, various scenarios may occur concerning the classification of the data which are observed [7]:

- complete data which mean accurate figures for random variables, e.g. the distance to failure is a specific number of kilometres covered by the vehicle until the failure is observed (Fig. 3a);

- right censored data, type I censorship - which occurs when only some vehicles failed during a specific time of operation. The time of observation is strictly specified, and the number of failed vehicles is a random variable (Fig. 3b);

- right censored data, type II censorship - observations are continued until a specific number of vehicles (fraction) fail;

- left censored data - apply to variables of which it is not known when they occurred in the past (when the vehicles failed). 
RAMS analysis of railway vehicles' lifecycle

Analiza RAMS w cyklu istnienia kolejowych środków transportu

Table 1. Codes of failures for diesel locomotives

\begin{tabular}{|c|l|}
\hline Group/Code & \multicolumn{1}{|c|}{ Description of failure } \\
\hline I. & LOCOMOTIVE'S OPERATOR \\
\hline 0 & Failures caused by improper service \\
\hline II. & LOCOMOTIVE'S POWER TRANSMISSION SYSTEM \\
\hline 500 & $\begin{array}{l}\text { IC engine (including fuel system, cooling system with fan and } \\
\text { pump, lubrication system, heat exchanger) }\end{array}$ \\
\hline 505 & Engine speed governor \\
\hline III. & LOCOMOTIVE ELECTRICAL SYSTEM \\
\hline 510 & Railway motors \\
\hline 515 & Master generator \\
\hline 520 & Auxiliary generator \\
\hline 525 & Converter \\
\hline 530 & Contactor \\
\hline 535 & $\begin{array}{l}\text { Other connectors (running controller, disconnecting switch, circuit } \\
\text { breaker, etc.) }\end{array}$ \\
\hline 540 & Relay (protective or control) \\
\hline 545 & Starting resistance \\
\hline 550 & Conductors (cables, rails, etc.) \\
\hline 555 & Storage batteries \\
\hline 560 & Other components of electrical circuits \\
\hline IV. & LOCOMOTIVE'S PNEUMATIC AND BRAKING SYSTEMS \\
\hline 565 & Master or auxiliary compressor, \\
\hline 570 & Master or auxiliary compressor driving motor, \\
\hline 575 & $\begin{array}{l}\text { Pneumatic valve (including driver's master or auxiliary valve, } \\
\text { pressure reducing valve, stop valve, safety valve), }\end{array}$ \\
\hline 580 & Freeze protection \\
\hline 585 & Pneumatic conductors \\
\hline 590 & Servo-motor in braking system \\
\hline 595 & Other elements in pneumatic circuit \\
\hline V. & LOCOMOTIVE'S RUNNING GEAR MECHANICAL SYSTEM \\
\hline 600 & Axle set bearings (including traction engine mounting bearings), \\
\hline 605 & elements of axle sets, \\
\hline 610 & springing elements (e.g. leaf spring, rubber elements), \\
\hline 615 & $\begin{array}{l}\text { brake element except pneumatic rams (e.g. e.g. levers, brake rods, } \\
\text { pins, sleeves, connectors, brake shoes), }\end{array}$ \\
\hline 620 & other elements of running gear. \\
\hline VI. & $\begin{array}{l}\text { VEHICLE MOTION SAFETY AUTOMATIC CONTROL } \\
\text { DEVICES }\end{array}$ \\
\hline 625 & $\begin{array}{l}\text { sensors (e.g. SHP, KHP, CZUWAK), measurement instruments } \\
\text { (speedometer, ammeter) or radio-telephone, }\end{array}$ \\
\hline OTHER SYSTEMS OF VEHICLE \\
\hline Elements of cars heating system, \\
\hline Vehicle body \\
\hline 55 & \\
\hline
\end{tabular}


a)

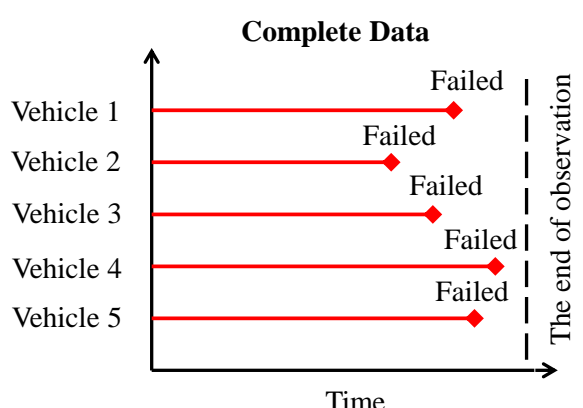

b)

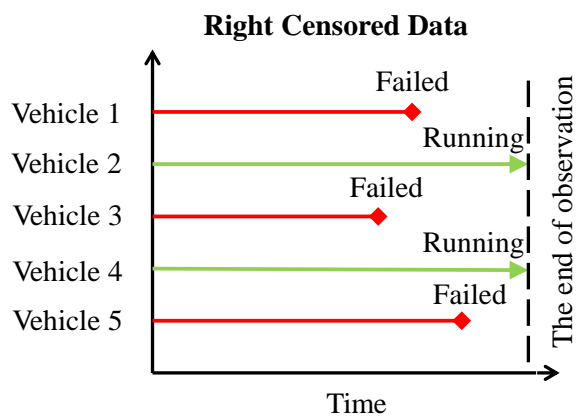

Fig. 3. Operational data for railway means of transport:

a) complete data, b) right censored data

\section{RAMS indicators for railway means of transport}

The RAMS properties are described by various quantitative or qualitative indicators. Their choice depends on the object which is examined and the aim of the analysis. The conclusion based on a review of specialist writings on the assessment of reliability, availability, maintainability and safety and recommendations following from the applicable standard PN-EN 50126 is that the set of indicators listed Tables $2 \div 5$ [3] can be applied in the RAMS analysis of railway means of transport. Detailed definitions of these indicators are provided in the following standards:

- PN-EN 50126 Railway Applications - The Specification and Demonstration of Reliability, Availability, Maintainability and Safety;

- PN-EN 61703 Mathematical Expressions concerning Reliability, Availability, Maintainability an Railway Applications - The Specification and Demonstration of Reliability, Availability, Maintainability and Maintenance Support Measures.

Selected reliability indicators for railway means of transport are presented in Table 2. $\mathrm{Z}(\mathrm{c})$ is the probability that the occurrence of the hazardous event " $\mathrm{A}$ " will cause losses smaller than "c" [15]. This standard does not take into account the indicator $\mathrm{Z}$ (c) which is relevant for the purposes of the RAMS analysis for railway means of transport.

The application of specific reliability, availability, maintainability and safety indicators depends, inter alia, on the type of the object of analysis and the conditions in which it is operated. A certain tendency can now be noted concerning the development of new indicators in the RAMS analysis. This relates to the fact that the standard PN-EN 50126 does not cover in a comprehensive manner many scenarios in the actual operation of railway means of transport [2]. 
RAMS analysis of railway vehicles' lifecycle

Analiza RAMS w cyklu istnienia kolejowych środków transportu

Table 2. Reliability indicators for railway means of transport

\begin{tabular}{|l|c|c|}
\hline \multicolumn{1}{|c|}{ Parameter } & Symbol & Unit \\
\hline Failure Rate & $\lambda(\mathrm{t})$ & {$[$ No. of fail./hr] } \\
\hline Mean Up Time & MUT & {$[\mathrm{hr}]$} \\
\hline Mean Time To Failure & MTTF & {$[\mathrm{hr}]$} \\
\hline Mean Distance to Failure & MDTF & {$[\mathrm{km}]$} \\
\hline Mean Time Between Failure & MTBF & {$[\mathrm{hr}]$} \\
\hline Medium Distance Between Failure & MDBF & {$[\mathrm{km}]$} \\
\hline $\begin{array}{l}\text { Distribution function of correct } \\
\text { operation time }\end{array}$ & $\mathrm{F}(\mathrm{t})$ & Zero-dimensional \\
\hline Reliability function & $\mathrm{R}(\mathrm{t})$ & Zero-dimensional \\
\hline
\end{tabular}

Table 3. Maintainability indicators for railway means of transport

\begin{tabular}{|l|c|c|}
\hline \multicolumn{1}{|c|}{ Parameter } & Symbol & Unit \\
\hline Medium Down Time & MDT & {$[\mathrm{hr}]$} \\
\hline $\begin{array}{l}\text { Medium Time/Distance to } \\
\text { Maintenance }\end{array}$ & MTBM/MDBM & {$[\mathrm{hr}],[\mathrm{km}]$} \\
\hline $\begin{array}{l}\text { Mean Time /Distance Between } \\
\begin{array}{l}\text { Maintenance (corrective, c) or } \\
\text { (preventive, } \text { p) }\end{array}\end{array}$ & $\begin{array}{l}\text { MTBM(c)/MDBM(c), } \\
\operatorname{MTBM(p)/MDBM(p),~}\end{array}$ & {$[\mathrm{hr}],[\mathrm{km}]$} \\
$\begin{array}{l}\text { Mean Time To (planned) } \\
\text { Maintenance }\end{array}$ & $\operatorname{MTTM(p)}$ & {$[\mathrm{hr}]$} \\
\hline Mean Time To Repair & MTTR & {$[\mathrm{hr}]$} \\
\hline
\end{tabular}

Table 4. Availability indicators for railway means of transport

\begin{tabular}{|l|c|c|}
\hline \multicolumn{1}{|c|}{ Parameter } & Symbol & Unit \\
\hline Instantaneous availability & $\mathrm{A}(\mathrm{t})$ & Zero-dimensional \\
\hline Operational availability & $\mathrm{A}_{\mathrm{o}}$ & Zero-dimensional \\
\hline Actual availability & $\mathrm{A}_{\mathrm{r}}$ & Zero-dimensional \\
\hline
\end{tabular}

Table 5. Safety indicators for railway means of transport

\begin{tabular}{|l|c|c|}
\hline \multicolumn{1}{|c|}{ Parameter } & Symbol & Unit \\
\hline $\begin{array}{l}\text { Probability of a hazardous event } \\
\text { in the time ,t" }\end{array}$ & $\mathrm{F}_{\mathrm{H}}(\mathrm{t})$ & Zero-dimensional \\
\hline Mean Time To Hazardous Failure & MTTHF & {$[\mathrm{hr}]$} \\
\hline $\begin{array}{l}\text { Mean Time Between Hazardous } \\
\text { Failures }\end{array}$ & MTBHF & {$[\mathrm{hr}]$} \\
\hline $\begin{array}{l}\text { Mean probability of a hazardous } \\
\text { event }\end{array}$ & $\mathrm{H}$ & Zero-dimensional \\
\hline $\begin{array}{l}\text { Consequences of a hazardous } \\
\text { event }\end{array}$ & $\mathrm{Z}(\mathrm{c})$ & $\begin{array}{c}\text { Human casualties, } \\
\text { financial losses }\end{array}$ \\
\hline
\end{tabular}




\section{Conclusions}

The paper presents selected aspects relating to the RAMS analysis of railway means of transport. The subject addressed in the paper results from considerable interest of the railway sector represented by railway manufacturers, modernisation contractors, entities responsible for the maintenance of vehicle and railway carriers in determining the reliability of means of transport. The process of determining the RAMS properties which comprises the stages of concept development and definition, design, manufacture and operation of means of transport is described following the methodological guidelines contained in the standard PN-EN 50126. The RAMS analysis uses various indicators which characterise reliability, availability, maintainability and safety. The selected ones are presented in this paper. Reliability indicators are determined on the basis of operation data and hence the paper also contains a classification of operation data based on various scenarios relating to the use and operation of railway means of transport.

\section{References}

[1] Adamkiewicz W., Hempel L., Podsiadło A., Śliwiński R., Badania i ocena niezawodności maszyny w systemie transportowym, WKiŁ, Warszawa 1983.

[2] Allan J. J., Arias E., Computer in Railways XI: Computer System Design and Operation in the Railway and Other Transit Systems. WIT Press, 2008.

[3] Babeł M., Szkoda M.: Diesel locomotive efficiency and reliability improvement as a result of power unit load control system modernisation. Eksploatacja i Niezawodnosc - Maintenance and Reliability 2016; 18(1): 38-49.

[4] DoD Guide for Achieving Reliability, Availability and Maintainability. Systems Engineering for Mission Success. Department of Defense USA 2005.

[5] Manzini R., Regattieri A., Pham H., Ferrari E.: Maintenance for Industrial Systems, Springer, 2010.

[6] Młynarski S., Pilch R., Smolnik M., Kaczor G., Szkoda M., Szybka J.: Effect of Selected Factors on The Safety Integrity Level (SIL). Journal of KONBiN 3(35) 2015: 85-98.

[7] Młyńczak M.: Analiza danych eksploatacyjnych w badaniach niezawodności obiektów technicznych, Zeszyty Naukowe Wyższej Szkoły Oficerskiej Wojsk Lądowych im. gen. T. Kościuszki, nr 1, 2011.

[8] Młyńczak M.: Metodyka badań eksploatacyjnych obiektów mechanicznych, Oficyna Wydawnicza Politechniki Wrocławskiej, Wrocław 2012.

[9] Oprzędkiewicz J.: Niezawodność maszyn, Skrypty Uczelniane Politechniki Świętokrzyskiej, Kielce 1981.

[10] PN-EN 50126 Zastosowania kolejowe - Specyfikacja niezawodności, dostępności, podatności utrzymaniowej i bezpieczeństwa.

[11] Rozporząazenie Wykonawcze Komisji Europejskiej (UE) nr 402/2013 z dnia 30 kwietnia 2013 r. w sprawie wspólnej metody oceny bezpieczeństwa w zakresie wyceny i oceny ryzyka i uchylające rozporządzenie (WE) nr 352/2009 (Dz. U. UE L121 z 03.05.2013). 
RAMS analysis of railway vehicles' lifecycle

Analiza RAMS w cyklu istnienia kolejowych środków transportu

[12] Stapelberg R. F.: Handbook of reliability, availability, maintainability and safety in engineering design, Springer Science \& Business Media, 2009.

[13] Szkoda M.: Analysis of Reliability, Availability and Maintainability (RAM) of SM48 Diesel Locomotive. 22nd International Symposium EURO-ZEL 2014, June 2014, Żilina, Słowacja.

[14] Szkoda M.: Assessment of Reliability, Availability and Maintainability of Rail Gauge Change Systems, Eksploatacja i Niezawodnosc - Maintenance and Reliability 2014; 16(3): 422-432.

[15] Szopa T.: Niezawodność i bezpieczeństwo, Oficyna Wydawnicza Politechniki Warszawskiej, 2009.

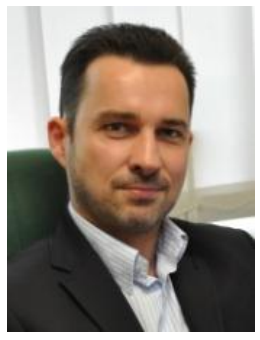

Dr inz. Maciej Szkoda jest absolwentem Wydziatu Mechanicznego Politechniki Krakowskiej. Pracuje w Instytucie Pojazdów Szynowych PK na stanowisku adiunkta naukowodydaktycznego. Pelni funkcje Kierownika Pracowni Systemów Logistycznych. Specjalizuje się $w$ ocenie efektywności i niezawodności systemów i środków transportu. (Udziat 50\%)

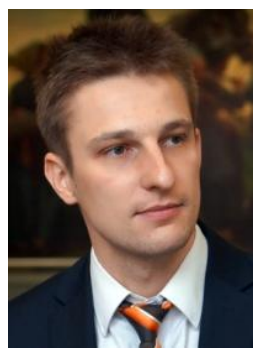

Mgr inż. Grzegorz Kaczor ukończyt studia magisterskie na Wydziale Mechanicznych Politechniki Krakowskiej, gdzie kontynuuje nauke na studiach III - ego stopnia. Pracuje w Instytucie Pojazdów Szynowych PK na stanowisku asystenta naukowo-dydaktycznego. Glówne obszary zainteresowania to ocena niezawodność $i$ bezpieczeństwa środków transportu $z$ wykorzystaniem metod symulacyjnych. (Udziat 50\%) 


\section{ANALIZA RAMS W CYKLU ISTNIENIA KOLEJOWYCH ŚRODKÓW TRANSPORTU}

\section{Wstęp}

Pojazdy kolejowe należą do złożonych obiektów technicznych, charakteryzujących się wysokimi kosztami zakupu, eksploatacji oraz długim okresem użytkowania, dla których zbiór parametrów opisujących etapy definiowania, projektowania, wytwarzania i eksploatacji jest bardzo obszerny i zróżnicowany. Obiekty te są projektowane pod kątem spełnienia wymagających przepisów bezpieczeństwa użytkowania i muszą charakteryzować się możliwie najniższą intensywnością występowania zdarzeń niepożądanych, które mogą zakłócić ich poprawne funkcjonowanie. Bezpieczeństwo kolejowych środków transportu jest ściśle związane $\mathrm{z}$ ich niezawodnością, która może być kształtowana na etapie projektowania, wytwarzania oraz eksploatacji. Zapewnienie wymaganego poziomu niezawodności jest $\mathrm{z}$ kolei uwarunkowane m.in. odpowiednio zaprojektowanym systemem utrzymania, uwzględniającym optymalną częstość i zakres wykonywania obsług. Plan systemu utrzymania kolejowych środków transportu musi być tak opracowany aby umożliwiać wczesne wykrywanie co najmniej krytycznych uszkodzeń w celu zachowania wymaganego poziomu bezpieczeństwa. Wykonywanie czynności obsługowych (zwłaszcza tych bieżących) kolejowych środków transportu wiąże się z ponoszeniem kosztów, w związku z tym budowanie modeli matematycznych dla potrzeb prognozowania częstości obsług wydaje się być w pełni uzasadnione.

Analiza RAMS (z ang. Realibility, Avalability, Maintainbility and Safety w skrócie RAMS) jest powszechnie stosowanym narzędziem dla potrzeb różnych gałęzi przemysłu, w szczególności transportu kolejowego. Pomimo znacznego potencjału wspomnianej metody, zauważyć można pewne braki w standaryzacji procedur obliczeniowych, zwłaszcza jeśli chodzi o wyznaczanie miar (wskaźników) związanych z niezawodnością kolejowych środków transportu. W normie PN-EN 50126 Zastosowania kolejowe - Specyfikacja niezawodności, dostępności, podatności utrzymaniowej $i$ bezpieczeństwa [10] znajdują się wytyczne dotyczące możliwości aplikacyjnych analizy RAMS w sektorze kolejowym, jednakże nie wyczerpują one w pełni niektórych aspektów praktycznych.

Celem analizy RAMS jest wykorzystanie informacji eksploatacyjnych do przeprowadzenia oceny zgodności z wymaganiami, określonymi w normie PN-EN 50126. Wymagania te odnoszą się do konkretnych wskaźników nieuszkadzalności, gotowości technicznej, podatności na utrzymanie oraz bezpieczeństwa. Istotną rolę w analizie RAMS odgrywa dokładność informacji eksploatacyjnych. W związku $\mathrm{z}$ tym, dane te powinny być gromadzone przez przewoźników kolejowych ze szczególną starannością i umieszczane w specjalnych arkuszach bazodanowych. 
RAMS analysis of railway vehicles' lifecycle

Analiza RAMS w cyklu istnienia kolejowych środków transportu

Struktura bazy danych powinna zawierać możliwe jak najdokładniejszy opis przyczyny uszkodzen, zarejestrowany czas ich wystąpienia oraz zakres opis podjętych działań obsługowych. Istotny jest również szybki dostęp do zawartości arkuszy [6].

W niniejszej pracy omówiono zastosowanie analizy RAMS w cyklu istnienia kolejowych środków transportu. Przytoczone zostały najważniejsze pojęcia oraz wskaźniki służące do oceny szeroko rozumianej niezawodności kolejowych środków transportu, zgodnie z normą PN-EN 50126.

\section{Podstawowe pojęcia związane $z$ analizą RAMS kolejowych środków transportu}

Niezawodność kolejowych środków transportu jest to cecha zbiorcza obejmująca takie własności pojazdu jak: nieuszkadzalność, gotowość, podatność na utrzymanie i bezpieczeństwo (rys. 1).

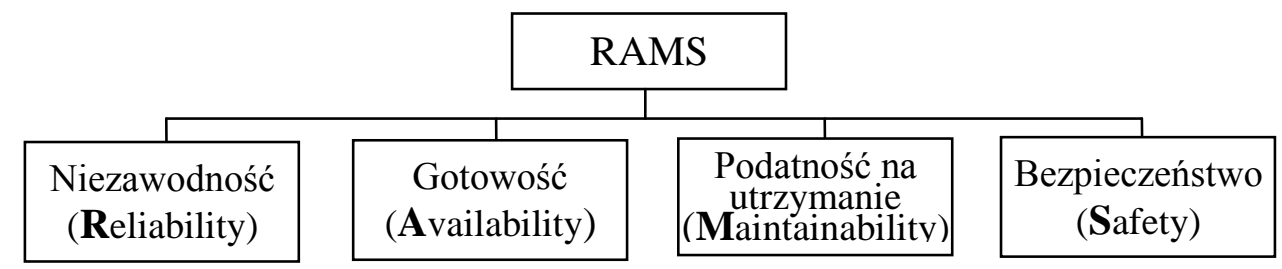

Rys. 1. Składowe RAMS kolejowych środków transportu

Wytyczne dotyczące analizy RAMS dla kolejowych środków transportu ujęte są w normie PN-EN 50126 Zastosowania kolejowe - Specyfikacja niezawodności, dostępności, podatności utrzymaniowej $i$ bezpieczeństwa. Cechy te można zdefiniować następująco [10, 12, 13]:

Nieuszkadzalność rozumiana jest jako zdolność pojazdu do wypełnienia wymaganych funkcji w danych warunkach eksploatacji i w danym przedziale czasu.

Gotowość to zdolność pojazdu do utrzymywania się w stanie umożliwiającym wypełnienie wymaganych funkcji $\mathrm{w}$ danych warunkach, $\mathrm{w}$ danej chwili lub w danym przedziale czasu, przy założeniu, że dostarczane są wymagane środki zewnętrzne.

Podatność na utrzymanie definiuje się jako właściwość charakteryzującą przystosowanie do wykonywania obsług w celu odtworzenia stanu zdatności $\mathrm{w}$ określonych warunkach eksploatacji $\mathrm{z}$ wykorzystaniem ustalonych metod i środków.

Bezpieczeństwo oznacza brak niedopuszczalnego ryzyka, które opisuje częstotliwość wypadków i incydentów prowadzących do szkody (spowodowanej zagrożeniem) oraz stopień powagi tej szkody [11]. Wg definicji przedstawionej w normie PN-EN 50126 bezpieczeństwo oznacza brak katastrofalnych skutków dla użytkownika i środowiska. 


\section{Kształtowanie RAMS w cyklu istnienia kolejowych środków transportu}

Według normy PN-EN 50126, analiza RAMS to proces projektowania, monitorowania i poprawy wskaźników nieuszkadzalności, gotowości, podatności na utrzymanie i bezpieczeństwa w cyklu istnienia pojazdu szynowego. Proces kształtowania charakterystyk RAMS, który przedstawiono schematycznie na rysunku 2, jest to proces wieloetapowy. Przebiega przez wszystkie etapy cyklu istnienia pojazdu: od powstania koncepcji i projektowania poprzez wytwarzanie do eksploatacji.

$\mathrm{Na}$ pierwszym etapie procesu kształtowania charakterystyk RAMS następuje określenie docelowych parametrów RAMS. W tym celu ważne jest uwzględnienie wymagań i potrzeb klienta. Klientem może być przedsiębiorstwo transportu kolejowego, które będzie pojazd eksploatować. Na rynku amerykańskim w celu poznania preferencji klienta stosowane są znormalizowane formularze, którego wzór przedstawiono w wytycznych Ministerstwa Obrony USA: DoD Guide for Achieving Reliability, Availability and Maintainability [4]. Również wartościowa jest identyfikacja parametrów pojazdów podobnego typu oferowanych na rynku przez konkurencję.

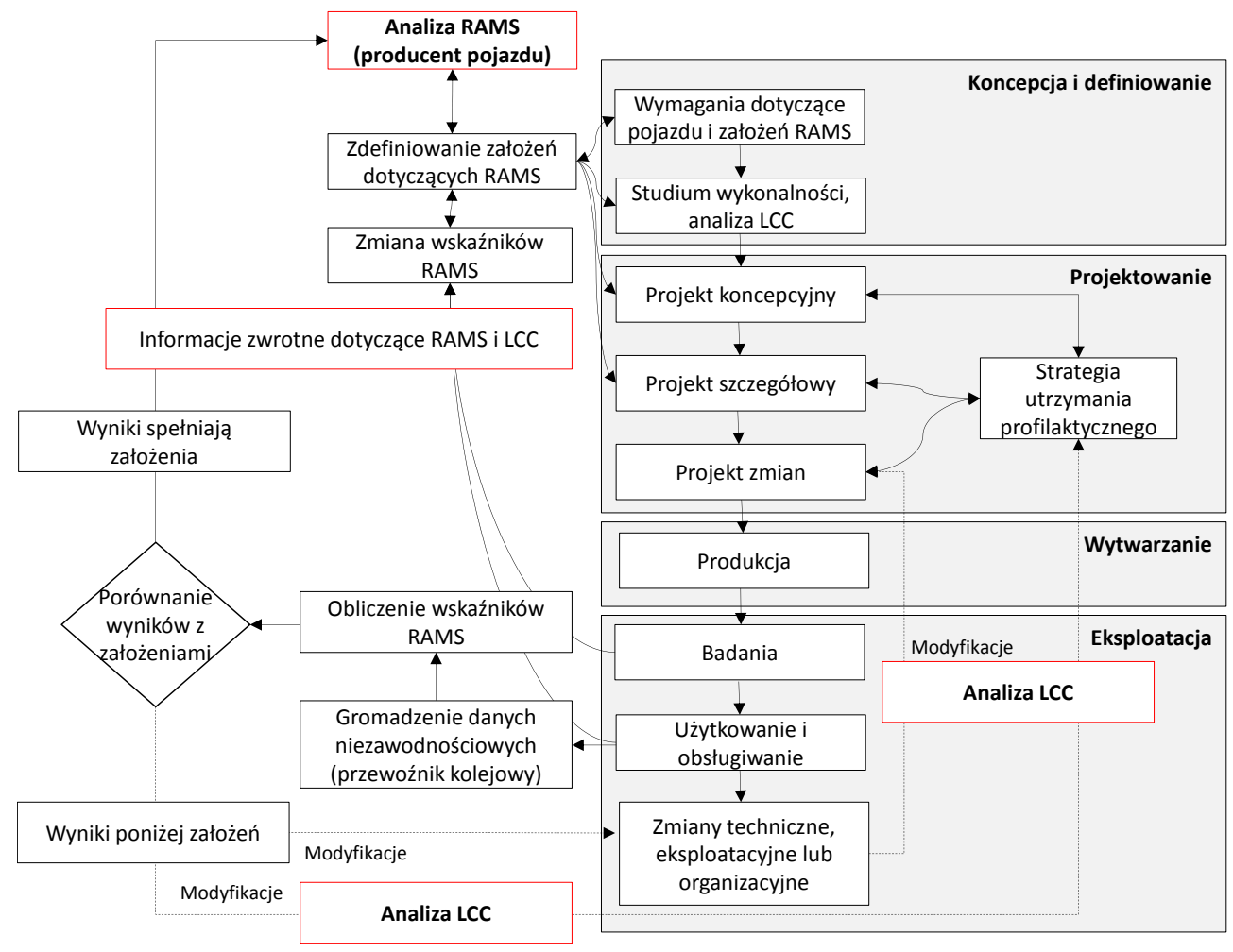

Rys. 2. Proces ksztaltowania charakterystyk RAMS kolejowych środków transportu 
RAMS analysis of railway vehicles' lifecycle

Analiza RAMS w cyklu istnienia kolejowych środków transportu

Po fazie definicji i koncepcji proces kształtowania charakterystyk RAMS przebiega przez etap projektowania pojazdu. Najbardziej efektywne ekonomicznie jest kształtowanie poziomu niezawodności w fazie projektowania. Oznacza to, że do osiągnięcia zamierzonego poziomu niezawodności potrzeba $\mathrm{w}$ tej fazie na ogół zdecydowanie mniejszych nakładów niż w przypadku, gdy poziom ten jest osiągany w pozostałych fazach $\mathrm{w}$ wyniku dodatkowych działań, nieprzewidzianych $\mathrm{w}$ okresie projektowania. Można więc stwierdzić, że działania na rzecz niezawodności $\mathrm{w}$ fazie projektowania są szczególnie uzasadnione. Niektóre z nich są znane i stosowane od dawna. Mają one na ogół charakter jakościowy i nie wymagają od konstruktora znajomości teorii niezawodności. Do działań tego rodzaju można zaliczyć na przykład [15]:

- projektowanie obiektów mało skomplikowanych,

- racjonalne stosowanie zabezpieczeń, ograniczników i wskaźników,

- zapewnianie łatwej wymiany elementów (m.in. przez stosowanie modułowej konstrukcji niektórych fragmentów obiektu),

- zapewnianie projektowanemu obiektowi małej wrażliwości na błędy wykonania i błędy eksploatacji,

- projektowanie sposobów zmniejszania intensywności zjawisk fizycznych pogarszających stan techniczny obiektu w okresie eksploatacji (np. obniżanie poziomu wytężeń, dobór odpowiednich materiałów, eliminowanie niepożądanych drgań),

- dobór odpowiednich sposobów wytwarzania (m.in. obróbek cieplnochemicznych),

- formułowanie odpowiednich wymagań w instrukcjach montażu, użytkowania i obsługi (dotyczących m.in. odnawiania profilaktycznego i diagnozowania stanu technicznego),

- właściwe odwzorowywanie procesu eksploatacji na etapie doświadczalnych badań prototypu,

- organizowanie systemu zbierania i przesyłania informacji o obiekcie z faz wytwarzania i eksploatacji do fazy projektowania.

Możliwe są także inne działania na rzecz niezawodności projektowanego obiektu działania o charakterze ilościowym. Do ich stosowania jest konieczna znajomość podstaw analizy niezawodności, a więc przede wszystkim umiejętność probabilistycznego modelowania właściwości obiektu oraz zjawisk przebiegających w obiekcie i w jego otoczeniu podczas eksploatacji, prowadzących do niezdatności. Głównym celem analizy niezawodności, szczególnie prowadzonej w fazie projektowania pojazdu, powinno być wskazanie tych czynników, które mają największy wpływ na poziom jego niezawodności. Taki wynik analizy niezawodności umożliwia wybranie najskuteczniejszych sposobów poprawy niezawodności. Analizy niezawodności obiektów są zwykle przeprowadzane na ich modelach. W ogólnym przypadku niezawodnościowy model obiektu jest to układ, który pod względem niezawodności odwzorowuje obiekt rzeczywisty i zastępuje go w planowanych analizach niezawodności. 
Postać modelu zależy od wielu czynników, takich jak: rodzaj obiektu, cel badań, zasób posiadanych informacji o obiekcie i o jego otoczeniu itd.

W przypadku obiektu traktowanego jako obiekt złożony z elementów o znanej niezawodności, jego model niezawodnościowy sprowadza się w zasadzie do modelu jego struktury niezawodnościowej. W odniesieniu do kolejowych środków transportu zastosowanie mają struktury szeregowe, równoległe, z rezerwą czy progowe typu $k \begin{array}{llllll} & & n & {[5,9,} & 15] \text {. Przykłady modelowania struktur }\end{array}$ niezawodnościowych dla kolejowych systemów przestawczych przedstawiono w pracy [14].

Projektowanie pojazdu powinno przebiegać równolegle $\mathrm{z}$ oceną podatności utrzymaniowej zespołów i podzespołów oraz opracowaniem strategii utrzymania. Poprzez różne rozwiązania konstrukcyjne, modułową budowę, zapewnienie łatwego dostępu do podzespołów istnieje możliwość wpływu na sposób realizacji procesów utrzymania. W miarę jak powstaje konstrukcja pojazdu, zmiany charakterystyk RAMS są coraz trudniejsze. Zapewnienie właściwych parametrów RAMS na etapie wytwarzania dotyczy między innymi zastosowania właściwych metod zapewnienia jakości. Po wyprodukowaniu pojazd trafia do eksploatacji. Początkowo do tzw. eksploatacji nadzorowanej w celu przeprowadzenia niezbędnych badań związanych z zezwoleniem na dopuszczenie do eksploatacji, a następnie do właściwej eksploatacji handlowej.

Faza eksploatacji stanowi istotne źródło informacji w kształtowaniu charakterystyk RAMS kolejowych środków transportu. Pod pojęciem informacji eksploatacyjnych należy rozumieć wszelkie dane o zjawiskach zachodzących w sferze eksploatacji pojazdów, czyli w sferze ich użytkowania i obsługiwania. Dane te można wykorzystać do celów planowania i zarządzania eksploatacją, do udoskonalenia technologii i konstrukcji eksploatowanych pojazdów, jak również do kontroli wskaźników RAMS. Takie określenie informacji eksploatacyjnych pozwala na identyfikowanie ich z informacją ekonomiczną, dotyczącą realizacji procesów eksploatacji oraz informacją techniczną, charakteryzującą pojazdy w warunkach ich eksploatowania.

Informacje eksploatacyjne odgrywają istotną rolę dla przewoźników użytkujących pojazdy, gdyż umożliwiają właściwe planowanie eksploatacji, planowanie przeglądów i napraw oraz ocenę wykorzystania środków transportu [10]. Z punktu widzenia producenta pojazdu (lub jego komponentów) informacje eksploatacyjne stanowią instrument kontrolny i źródło danych porównawczych do oceny realizacji założonego poziomu technicznego, umożliwiają zdobywanie danych o niezbędnej ilości części zamiennych i kosztach eksploatacji, stanowią formę wymiany informacji z użytkownikiem w celu rozpoznawania jego potrzeb, życzeń i uwag. Informacje dotyczące wskaźników RAMS i generowanych kosztów, można podzielić jako:

- informacje operacyjne stanowiące podstawę do bieżącego sterowania procesami,

- informacje awaryjne powiadamiające o nieprawidłowym działaniu pojazdu. 
RAMS analysis of railway vehicles' lifecycle

Analiza RAMS w cyklu istnienia kolejowych środków transportu

Informacje awaryjne stanowią podstawę do tworzenia statystycznej oceny pojawiających się zdarzeń niepożądanych. W dłuższej perspektywie czasu archiwizowane dane mogą budować bazę danych o różnych zmiennych opisujących proces działania. Zmienne takie mają postać zmiennych dyskretnych (liczba zdarzeń) lub zmiennych ciągłych (zmienne opisujące czas, wydajność, przebieg itp.). W literaturze istnieją prace poświęcone tworzeniu profesjonalnych systemów informacyjnych stosowanych w eksploatacji obiektów technicznych.

Jak to zostało przedstawione na rysunku 2, rzeczywiste dane zbierane przez przewoźnika związane ze statystyką uszkodzeń i odnów stanowią informację zwrotną dla fazy projektowania. Jeżeli poziom niezawodności pojazdu jest niezadowalający, możliwe jest wprowadzenie zmian konstrukcyjnych, eksploatacyjnych lub organizacyjnych $\mathrm{w}$ celu osiągniecia wymaganego poziomu niezawodności i bezpieczeństwa. Wymaga to współpracy i wymiany danych pomiędzy przewoźnikiem eksploatującym pojazd, podmiotem zajmującym się utrzymaniem a producentem pojazdu.

\section{4. Źródła danych do analizy niezawodnościowej RAMS}

Ocena niezawodności kolejowych środków transportu wymaga zgromadzenia i przetworzenia wiarygodnych danych eksploatacyjnych. Takie dane gromadzi się w wyniku obserwacji procesu eksploatacji prowadzonych w sposób bierny lub czynny. W czynnym eksperymencie obserwacyjnym gromadzi się określone, wybrane pod kątem spełnienia celu badań dane, co wymaga zastosowania specjalnych procedur i formularzy zbierania danych [1,8]. Bierna obserwacja eksploatacji polega na przetworzeniu danych istniejących, zapisanych w rutynowej dokumentacji przewoźnika. W przypadku pojazdów trakcyjnych będą to np.:

- książki napraw bieżących,

- książki napraw i przeglądów okresowych,

- książki pojazdów trakcyjnych i inne.

Wśród polskich przewoźników kolejowych obserwuje się coraz częściej wykorzystanie zaawansowanych systemów informatycznych wspomagających zarządzanie potencjałem przewozowym (jak Elektroniczna Księga Logistyki w PKP Cargo S.A.). Stosowane są również proste aplikacje oparte na wykorzystaniu programu Microsoft Excel, które bardzo ułatwiają gromadzenie i analizę danych eksploatacyjnych stanowiących podstawę oceny niezawodnościowej. Przykład struktury arkusza MS Excel wykorzystywanego do gromadzenia danych eksploatacyjnych związanych $\mathrm{z}$ naprawami bieżącymi pojazdów trakcyjnych przedstawiono $\mathrm{w}$ tabeli 1 . Kluczowym problemem $\mathrm{w}$ tego typu narzędziach jest stworzenie uniwersalnego katalogu uszkodzeń w podziale na zespoły i podzespoły pojazdu (tzw. kod uszkodzenia). W tabeli 1 przedstawiono przykład takich rejestrów stosowanych dla lokomotyw spalinowych w przedsiębiorstwie PKP Cargo S.A., które mogą stanowić wzór dla innych polskich przewoźników kolejowych. 
Tabela 1. Kody uszkodzeń dla lokomotyw spalinowych

\begin{tabular}{|c|c|}
\hline $\begin{array}{c}\text { Grupa/Kod } \\
\text { uszkodzenia }\end{array}$ & Opis uszkodzenia \\
\hline I. & USZKODZENIA WYWOLANE BLĘDAMI OPERATORA \\
\hline 0 & niewłaściwa obsługa pojazdu trakcyjnego \\
\hline II. & USZKODZENIA SILNIKA SPALINOWEGO \\
\hline 500 & $\begin{array}{l}\text { uszkodzenie silnika spalinowego (w tym także; instalacji paliwowej, układu } \\
\text { chłodzenia łącznie z wentylatorem i pompa, układu smarowania, wymiennika } \\
\text { ciepła), }\end{array}$ \\
\hline 505 & uszkodzenie regulatora obrotów silnika spalinowego. \\
\hline III. & $\begin{array}{l}\text { USZKODZENIA W OBWODACH ELEKTRYCZNYCH POJAZDU } \\
\text { TRAKCYJNEGO }\end{array}$ \\
\hline 510 & uszkodzenie silnika trakcyjnego, \\
\hline 515 & uszkodzenie prądnicy głównej, \\
\hline 520 & uszkodzenie prądnicy pomocniczej, \\
\hline 525 & uszkodzenie przetwornicy, \\
\hline 530 & uszkodzenie stycznika, \\
\hline 535 & uszkodzenie pozostałych łączników (nastawnik jazdy, odłącznik, wyłącznik itp.) \\
\hline 540 & uszkodzenie przekaźnika (zabezpieczającego lub kontrolnego), \\
\hline 545 & uszkodzenie oporu rozruchowego, \\
\hline 550 & uszkodzenie przewodów elektryczny \\
\hline 555 & uszkodzenie baterii akumulatorów, \\
\hline 560 & $\begin{array}{l}\text { uszkodzenie pozostałych elementów, aparatów i urządzeń obwodów } \\
\text { elektrycznych. }\end{array}$ \\
\hline IV. & $\begin{array}{l}\text { USZKODZENIA W OBWODACH PNEUMATYCZNYCH POJAZDU } \\
\text { TRAKCYJNEGO }\end{array}$ \\
\hline 565 & $\begin{array}{l}\text { uszkodzenie sprężarki głównej lub pomocniczej pojazdu trakcyjnego (za } \\
\text { wyjątkiem silnika napędzającego sprężarką), }\end{array}$ \\
\hline 570 & $\begin{array}{l}\text { uszkodzenie silnika napędzającego sprężarkę główną lub pomocniczą pojazdu } \\
\text { trakcyjnego, }\end{array}$ \\
\hline 575 & $\begin{array}{l}\text { uszkodzenie zaworu pneumatycznego (m.in. głównego lub pomocniczego } \\
\text { zaworu maszynisty, zaworu redukcyjnego, końcowego, bezpieczeństwa), }\end{array}$ \\
\hline 580 & zamrożenie układu pneumatycznego pojazdu trakcyjnego, \\
\hline 585 & uszkodzenie przewodów pneumatycznych, \\
\hline 590 & uszkodzenie siłownika w układzie hamulcowym pojazdu trakcyjnego, \\
\hline 595 & pozostałe uszkodzenia w obwodzie pneumatycznym pojazdu trakcyjnego. \\
\hline V. & $\begin{array}{l}\text { USZKODZENIA ELEMENTOW MECHANICZNYCH PODWOZIA } \\
\text { POJAZDU TRAKCYJNEGO }\end{array}$ \\
\hline 600 & $\begin{array}{l}\text { uszkodzenie tożyska zestawu kołowego ( } \mathrm{w} \text { tym także łożyska zawieszenia } \\
\text { silnika trakcyjnego), }\end{array}$ \\
\hline 605 & uszkodzenie pozostałych elementów zestawów kołowych, \\
\hline 610 & $\begin{array}{l}\text { uszkodzenie elementu sprężynującego podwozia (np. resora piórowego, } \\
\text { elementu gumowego), }\end{array}$ \\
\hline 615 & $\begin{array}{l}\text { uszkodzenie elementu hamulca za wyjątkiem siłowników pneumatycznych (np. } \\
\text { dżwigni, ciagła, sworznia, tulejki, złączki, klocka hamulcowego), }\end{array}$ \\
\hline 620 & pozostałe uszkodzenia elementów podwozia pojazdu trakcyjnego. \\
\hline VI. & $\begin{array}{l}\text { USZKODZENIA URZADZEN CZUJNOSCI ORAZ PRZYRZĄDOW } \\
\text { POMIAROWYCH POJAZDU TRAKCYJNEGO }\end{array}$ \\
\hline 625 & $\begin{array}{l}\text { uszkodzenie urzadzenia czujności (np. SHP, KHP, CZUWAK), przyrządu } \\
\text { pomiarowego (prędkościomierz, amperomierz) lub radiotelefonu, }\end{array}$ \\
\hline VII. & POZOSTALE USZKODZENIA POJAZDU TRAKCYJNEGO \\
\hline 630 & uszkodzenia układu ogrzewania składu pociągu, \\
\hline 635 & uszkodzenia nadwozia. \\
\hline
\end{tabular}


RAMS analysis of railway vehicles' lifecycle

Analiza RAMS w cyklu istnienia kolejowych środków transportu

Podczas gromadzenia danych eksploatacyjnych i następnie ich analizy mogą wystąpić różne scenariusze dotyczące klasyfikacji obserwowanych danych [7]:

- dane pełne (kompletne), które oznaczają dokładne wartości realizacji zmiennych losowych np. przebieg do uszkodzenia jest konkretną liczbą kilometrów przebiegu pojazdu do chwili zaobserwowania uszkodzenia (rys 3a);

- dane ucięte prawostronne, ucięcie I typu - ucinanie typu I ma miejsce wówczas, gdy w określonym czasie eksploatacji tylko część pojazdów uległa uszkodzeniu. Czas obserwacji jest ściśle określony, a liczba uszkodzonych pojazdów jest zmienną losową (rys 3b);

- dane ucięte prawostronne, ucięcie II typu - obserwacje prowadzi się do chwili, kiedy określona liczba pojazdów (frakcja) ulegnie uszkodzeniu;

- dane ucięcie lewostronne, dotyczy zmiennych, o których nie wiadomo, kiedy w przeszłości pojawiły się (kiedy pojazdy uległy uszkodzeniu).

a)

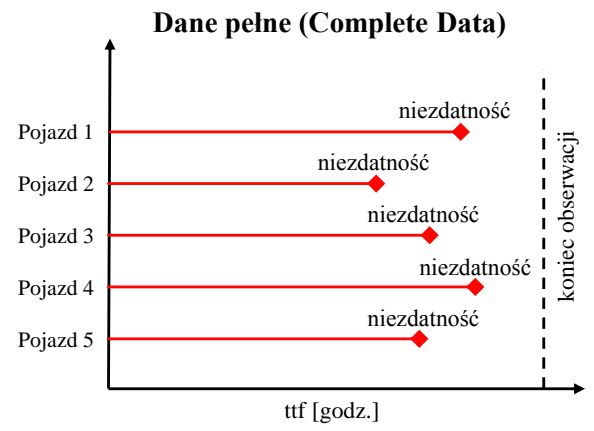

b)

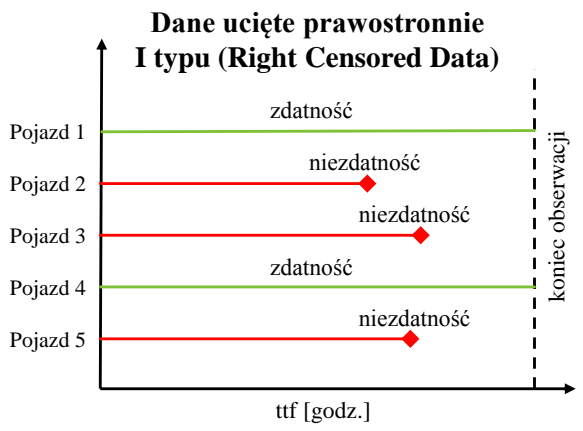

Rys. 3. Dane eksploatacyjne kolejowych środków transportu: a) dane kompletne, b) dane ucięte prawostronnie

\section{Wskaźniki RAMS kolejowych środków transportu}

Charakterystyki RAMS opisywane są przez różne wskaźniki o charakterze ilościowym lub jakościowym. Ich dobór zależy od obiektu będącego przedmiotem badań jak i od celu analizy. Na podstawie przeglądu specjalistycznej literatury dotyczącej oceny nieuszkadzalności, gotowości, podatności utrzymaniowej i bezpieczeństwa oraz uwzględniając zalecenia obowiązującej normy PN-EN 50126, stwierdzono, że w analizie RAMS kolejowych środków transportu można zastosować zestaw wskaźników wymienionych w tabelach $2 \div 5$ [3]. Szczegółowe definicje wymienionych wskaźników zawarte są w normach:

- PN-EN 50126 Zastosowania kolejowe - Specyfikacja niezawodności, dostęności, podatności utrzymaniowej i bezpieczeństwa;

- PN-EN 61703 Wyrażenia matematyczne dotyczace nieuszkadzalności, gotowości, obstugiwalności i zapewnienia środków obstugi.

Wybrane wskaźniki nieuszkadzalności kolejowych środków transportu przedstawiono w tabeli 2. 
Tabela 2. Wskaźniki nieuszkadzalności kolejowych środków transportu

\begin{tabular}{|l|c|c|}
\hline \multicolumn{1}{|c|}{ Parametr } & Oznaczenie & Jednostka \\
\hline Intensywność uszkodzeń & $\lambda(\mathrm{t})$ & [li. uszk./godz.] \\
\hline Średni czas zdatności & MUT & [godz.] \\
\hline Średni czas do uszkodzenia & MTTF & [godz.] \\
\hline Średni przebieg do uszkodzenia & MDTF & {$[\mathrm{km}]$} \\
\hline Średni czas między uszkodzeniami & MTBF & [godz.] \\
\hline $\begin{array}{l}\text { Średni przebieg między } \\
\text { uszkodzeniami }\end{array}$ & MDBF & {$[\mathrm{km}]$} \\
\hline $\begin{array}{l}\text { Dystrybuanta czasu poprawnej } \\
\text { pracy }\end{array}$ & $\mathrm{F}(\mathrm{t})$ & Bezwymiarowe \\
\hline Funkcja niezawodności & $\mathrm{R}(\mathrm{t})$ & Bezwymiarowe \\
\hline
\end{tabular}

Tabela 3. Wskaźniki podatności na utrzymanie kolejowych środków transportu

\begin{tabular}{|l|c|c|}
\hline \multicolumn{1}{|c|}{ Parametr } & Oznaczenie & Jednostka \\
\hline Średni czas przestoju & MDT & [godz.] \\
\hline $\begin{array}{l}\text { Średni czas/przebieg między } \\
\text { obsługami }\end{array}$ & MTBM/MDBM & [godz.], [km] \\
\hline $\begin{array}{l}\text { Średni czas/przebieg między } \\
\text { obsługami, bieżącymi (ang. } \\
\text { corrective, c) lub profilaktycznymi } \\
\text { (ang. preventive, p) }\end{array}$ & $\begin{array}{c}\text { MTBM(c)/MDB } \\
\text { MT(c), }\end{array}$ & $\begin{array}{c}\text { MT(p)/MDB } \\
\text { [godz.], [km] }\end{array}$ \\
\hline $\begin{array}{l}\text { Sredni czas wykonania obsługi } \\
\text { planowej }\end{array}$ & MTTM(p) & [godz.] \\
\hline Sredni czas odnowy & MTTR & [godz.] \\
\hline
\end{tabular}

Tabela 4. Wskaźniki gotowości kolejowych środków transportu

\begin{tabular}{|l|c|c|}
\hline \multicolumn{1}{|c|}{ Parametr } & Oznaczenie & Jednostka \\
\hline Gotowość chwilowa & $\mathrm{A}(\mathrm{t})$ & Bezwymiarowe \\
\hline Gotowość operacyjna & $\mathrm{A}_{\mathrm{o}}$ & Bezwymiarowe \\
\hline Gotowość rzeczywista & $\mathrm{A}_{\mathrm{r}}$ & Bezwymiarowe \\
\hline
\end{tabular}

Tabela 5. Wskaźniki bezpieczeństwa kolejowych środków transportu

\begin{tabular}{|l|c|c|}
\hline \multicolumn{1}{|c|}{ Parametr } & Oznaczenie & Jednostka \\
\hline $\begin{array}{l}\text { Prawdopodobienstwo wystapienia } \\
\text { zdarzenia niepożądanego w czasie „t” }\end{array}$ & $\mathrm{F}_{\mathrm{H}}(\mathrm{t})$ & Bezwymiarowe \\
\hline $\begin{array}{l}\text { Oczekiwany czas pracy do zdarzenia } \\
\text { niepożądanego }\end{array}$ & MTTHF & [godz.] \\
\hline $\begin{array}{l}\text { Oczekiwany czas pracy między } \\
\text { zdarzeniami niepożądanymi }\end{array}$ & MTBHF & [godz.] \\
\hline $\begin{array}{l}\text { Częstość wystąpienia zdarzenia } \\
\text { niepożądanego }\end{array}$ & $\mathrm{H}$ & Bezwymiarowe \\
\hline $\begin{array}{l}\text { Skutki wystąpienia zdarzenia } \\
\text { niepożądanego }\end{array}$ & $\mathrm{Z}(\mathrm{c})$ & $\begin{array}{c}\text { Straty ludzkie, straty } \\
\text { finansowe }\end{array}$ \\
\hline
\end{tabular}


RAMS analysis of railway vehicles' lifecycle

Analiza RAMS w cyklu istnienia kolejowych środków transportu

Z(c) jest prawdopodobieństwem tego, że zajście zdarzenia niepożądanego „A” spowoduje straty nie mniejsze niż „c” [15]. Norma nie uwzględnia wskaźnika Z(c), który jest istotny dla potrzeb analizy RAMS w odniesieniu do kolejowych środków transportu.

Zastosowanie konkretnych wskaźników nieuszkadzalności, gotowości, podatności na utrzymanie oraz bezpieczeństwa zależy m.in. od rodzaju obiektu analizy, warunków eksploatacji. Aktualnie można zauważyć pewną tendencję dotyczącą opracowywania nowych wskaźników w analizie RAMS. Jest to związane z faktem, że norma PN-EN 50126 nie wyczerpuje w pełni wielu scenariuszy w rzeczywistej eksploatacji kolejowych środków transportu [2].

\section{Podsumowanie}

W pracy przedstawiono wybrane aspekty związane z analizą RAMS kolejowych środków transportu. Podjęty $\mathrm{w}$ pracy temat wynika $\mathrm{z}$ dużego zainteresowania sektora kolejowego reprezentowanego przez producentów kolejowych, wykonawców modernizacji, podmioty odpowiedzialne za utrzymanie pojazdów oraz przewoźników kolejowych, kształtowaniem niezawodności środków transportu. W oparciu o wytyczne metodologiczne zawarte w normie PN-EN 50126 omówiono proces kształtowania charakterystyk RAMS, obejmujący etapy w fazie koncepcji i definiowania, projektowania, wytwarzania oraz eksploatacji środków transportu. W analizie RAMS wykorzystywane są różne wskaźniki charakteryzujące nieuszkadzalność, gotowość techniczną, podatność na utrzymanie oraz bezpieczeństwo. Wybrane $\mathrm{z}$ nich zostały przedstawione w niniejszej pracy. Wyznaczenie wskaźników niezawodnościowych odbywa się na podstawie gromadzonych danych eksploatacyjnych, w związku z tym, prezentowane opracowanie zawiera także klasyfikację danych eksploatacyjnych, wynikającą z różnych scenariuszy związanych z użytkowaniem i obsługiwaniem kolejowych środków transportu.

\section{Literatura}

[1] Adamkiewicz W., Hempel L., Podsiadło A., Śliwiński R., Badania i ocena niezawodności maszyny w systemie transportowym, WKiŁ, Warszawa 1983.

[2] Allan J. J., Arias E., Computer in Railways XI: Computer System Design and Operation in the Railway and Other Transit Systems. WIT Press, 2008.

[3] Babeł M., Szkoda M.: Diesel locomotive efficiency and reliability improvement as a result of power unit load control system modernisation. Eksploatacja i Niezawodnosc - Maintenance and Reliability 2016; 18(1): 38-49.

[4] DoD Guide for Achieving Reliability, Availability and Maintainability. Systems Engineering for Mission Success. Department of Defense USA 2005.

[5] Manzini R., Regattieri A., Pham H., Ferrari E.: Maintenance for Industrial Systems, Springer, 2010. 
[6] Młynarski S., Pilch R., Smolnik M., Kaczor G., Szkoda M., Szybka J.: Effect of Selected Factors on The Safety Integrity Level (SIL). Journal of KONBiN 3(35) 2015: 85-98.

[7] Młyńczak M.: Analiza danych eksploatacyjnych w badaniach niezawodności obiektów technicznych, Zeszyty Naukowe Wyższej Szkoły Oficerskiej Wojsk Lądowych im. gen. T. Kościuszki, nr 1, 2011.

[8] Młyńczak M.: Metodyka badań eksploatacyjnych obiektów mechanicznych, Oficyna Wydawnicza Politechniki Wrocławskiej, Wrocław 2012.

[9] Oprzędkiewicz J.: Niezawodność maszyn, Skrypty Uczelniane Politechniki Świętokrzyskiej, Kielce 1981.

[10] PN-EN 50126 Zastosowania kolejowe - Specyfikacja niezawodności, dostępności, podatności utrzymaniowej i bezpieczeństwa.

[11] Rozporządzenie Wykonawcze Komisji Europejskiej (UE) nr 402/2013 z dnia 30 kwietnia 2013 r. w sprawie wspólnej metody oceny bezpieczeństwa $\mathrm{w}$ zakresie wyceny i oceny ryzyka i uchylające rozporządzenie (WE) nr 352/2009 (Dz. U. UE L121 z 03.05.2013).

[12] Stapelberg R. F.: Handbook of reliability, availability, maintainability and safety in engineering design, Springer Science \& Business Media, 2009.

[13] Szkoda M.: Analysis of Reliability, Availability and Maintainability (RAM) of SM48 Diesel Locomotive. 22nd International Symposium EURO-ZEL 2014, June 2014, Żilina, Słowacja.

[14] Szkoda M.: Assessment of Reliability, Availability and Maintainability of Rail Gauge Change Systems, Eksploatacja i Niezawodnosc - Maintenance and Reliability 2014; 16(3): 422-432.

[15] Szopa T.: Niezawodność i bezpieczeństwo, Oficyna Wydawnicza Politechniki Warszawskiej, 2009.

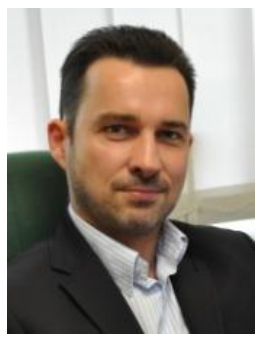

Dr inz. Maciej Szkoda jest absolwentem Wydziatu Mechanicznego Politechniki Krakowskiej. Pracuje w Instytucie Pojazdów Szynowych PK na stanowisku adiunkta naukowodydaktycznego. Pelni funkcję Kierownika Pracowni Systemów Logistycznych. Specjalizuje się $w$ ocenie efektywności i niezawodności systemów i środków transportu. (Udziat 50\%)

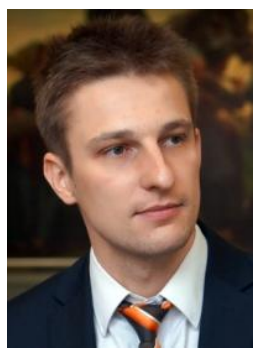

Mgr inz. Grzegorz Kaczor ukończyt studia magisterskie na Wydziale Mechanicznych Politechniki Krakowskiej, gdzie kontynuuje nauke na studiach III - ego stopnia. Pracuje w Instytucie Pojazdów Szynowych PK na stanowisku asystenta naukowo-dydaktycznego. Gtówne obszary zainteresowania to ocena niezawodność $i$ bezpieczeństwa środków transportu $z$ wykorzystaniem metod symulacyjnych. (Udziat 50\%) 
RAMS analysis of railway vehicles' lifecycle

Analiza RAMS w cyklu istnienia kolejowych środków transportu 